\title{
Flight, Climate Change, and Dangerous Times for Art and Pedagogy
}

\section{Video Essay and Digital Paper}

\author{
Andrew Denton \\ Art and Design, Auckland University of Technology, Auckland, \\ Auckland, Australia \\ adenton@aut.ac.nz \\ Andrew Gibbons \\ Department of Education, Auckland University of Technology, Auckland, \\ Auckland, Australia \\ andrew.gibbons@aut.ac.nz
}

\begin{abstract}
In his last book Chaosmosis, Felix Guattari (1995, p. 129) argues that both "intellectuals and artists have got nothing to teach anyone," and that they produce "toolkits composed of concepts, percepts and affects, which diverse publics will use at their convenience." In this video presentation and accompanying article, the authors explore Guattari's claim as a provocation for visual pedagogy and play with the idea that an artist might have nothing to teach anyone in relation to the idea of visual pedagogies. And, then, what happens when an artist and a teacher talk about visual pedagogies? To open up a dialogue, they employ the cliché, 'I don't know much about art but I know what I like'. This statement invites thoughts on the tensions between truth-telling, disciplinarity, and affect. Here the authors take the cliché a step further within the context of visual pedagogies and meaning making. They position this dialogue with the cinematic art work, Flight (2018), which aims to give the viewer a different sensation of the world, to render the familiar unfamiliar, and to let things be (Roder \& Sturm, 2017), in order to think differently.
\end{abstract}

\section{Keywords}

digital paper - visual pedagogy - cinematic affect - aesthetic rupture - sensation ecological emergency - poetic-cinematic language - education 


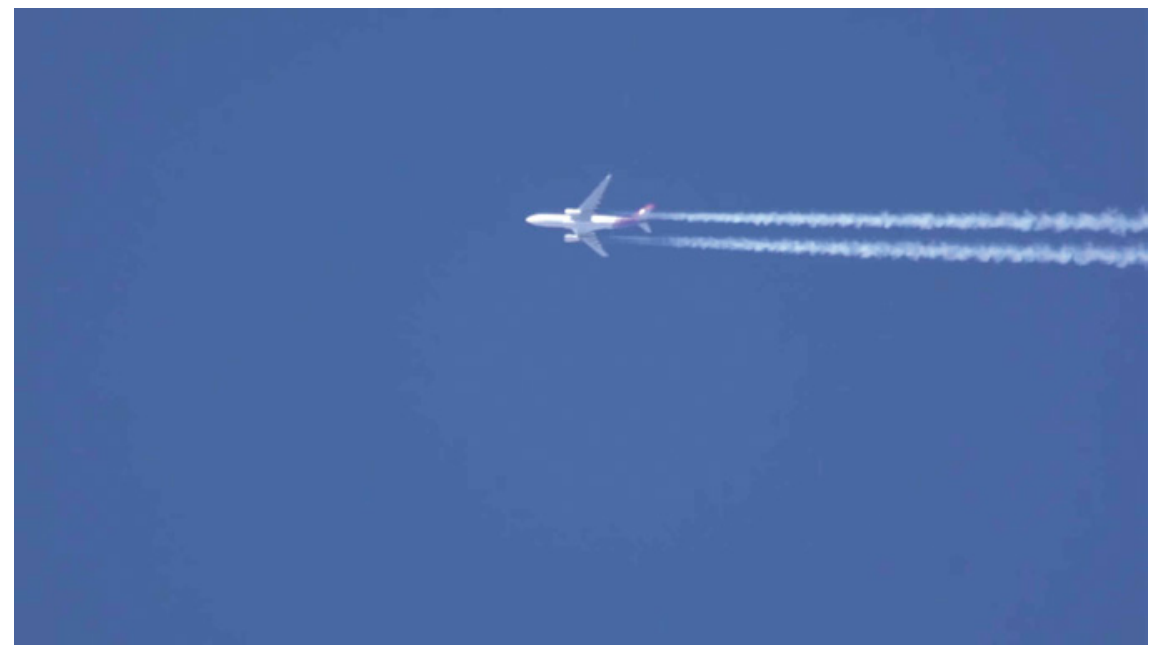

FEATURE Andrew Denton and Andrew Gibbons' article is based on the film 'Flight', which can be viewed here.

In a post-screening question and answer session of Flight (Denton, 2018a) an audience member challenged the film-artist. The challenge revolved around the idea that as a creative work Flight was essentially only going to 'preach to the converted'. In other words, anyone who didn't already take climate change seriously would be unmoved by Flight and would fail to see anything to learn. What pedagogical work should Flight do, and perhaps more importantly, what kind of pedagogy is Flight doing?

Perhaps Flight has already done its work in order for this question to be asked - it has already had some affect in inviting a viewer to question who is the audience and how should an audience experience what matters? Here, the visual pedagogical approach of Flight is specifically an invite to a viewer to search for their own questions rather than to debate facts and prescribe solutions. But, perhaps also we need not engage in questions concerning the pedagogical work of Flight through a reversion to text because we get caught in our own contradiction. Writing a piece of text to speak to what a cinematic work is saying, in other words, undermines the pedagogy of the cinema. Nevertheless, we will give it some attention in this text, but with a commitment to keeping space for Flight to do its 'thing' regardless and in spite of what we write here. In this article to accompany Flight we explore these questions and challenges through attention to the work of Rancière on emancipation and explication, and the problems of educational reform. 
In his last book, Chaosmosis: An Ethico-Aesthetic Paradigm, Felix Guattari (1995, p. 129) argues that both "intellectuals and artists have got nothing to teach anyone," and that they produce "toolkits composed of concepts, percepts and affects, which diverse publics will use at their convenience." Guattari's claim is a provocation for visual pedagogy. We see in this provocation an idea resonating with the challenge put to educational institutions in the work of Jacques Rancière:

The artist's emancipatory lesson, opposed on every count to the professor's stultifying lesson, is this: each one of us is an artist to the extent that he carries out a double process; he is not content to be a mere journeyman but wants to make all work a means of expression, and he is not content to feel something but tries to impart it to others. The artist needs equality as the explicator needs inequality.

RANCIÈRE, 1991, pp. 70-71

Visual pedagogy heads towards explication in those moments when the pedagogue's visual work takes up the task of explication through the translation to (for instance) the photograph or moving image, of a particular kind of explicatory lecture. These photographs and film demand the imagery to say what has already been written - what need do we have (to invert Camus, 1991) the soft lines of the hills against the sky if we have the scientific formulae?

The cinematic artwork, Flight, aims to give the viewer a different sensation of the world, to render the familiar unfamiliar, and paradoxically also at the same time to let things be (Roder \& Sturm, 2018), in order to think differently.

Flight is situated within a moving image research practice engaged with climate emergency. The making-thinking methods are aligned with essayist cinema and video installation, as well as historical avant-garde silent film. Flight along with Crude (Denton, 2018b), were initiated in response to subjective experiences of ecological devastation, which induced a personal state of melancholy in the artist. The practice works from the position that another tactic for progressing discourses around anthropogenic climate and geological change might be poetic or affective modes that are often present in the aforementioned moving image practices. The films aim to eschew 'fact' based representational modes, for contemplative, expressive and ambiguous registers of visual and aural inquiry. The aim is to give the viewer a different sensation of the world, to render the familiar unfamiliar in order to see, hear, feel, and be in the world differently (Denton, 2016a). 
As practice-oriented research, Flight's openness is connected intrinsically to its process of making. It emerged, somewhat organically, during the production of its companion piece (the essay film) Crude. Flight iterated gradually though being in the right place at the right time. Chance moments of fleeting glimpses of the jets flying by seen in Flight, were captured between moments in the field during the making of the other work (Crude). They only happened because of the other and created flicks of thought through the thinking-making processes attuned to the ecological emergency at the core of the project's central interests. "One day, as I filmed mirages on the Mojave Desert road I looked up for a fleeting moment to see a contrail. I filmed it, and then thousands more over the following year. They become symbolic gestures for the whole project" (Denton, 2016b, p. 197).

Both projects established creative constraints that harnessed a series of repeatable visual collection methods that in the case of Crude, connected disparate subjects collectively through modes of repetitive process, and alternately in Flight, took a repeated subject and highlighted their differences inside the constraints. Repetition is used as a method of poetic-cinematic language in a similar way it can be harnessed in the written. From a technical point of view, both projects enlisted the use of slow motion $(200+$ frames per second) cinematography, combined with extreme telephoto lenses. The resulting moving image slows down time and compresses space in the frame. The visual methods were deployed to achieve both a rendering of the familiar unfamiliar, but also to make what is in day-to-day encounters invisible more acutely visible, seeing the world through a different lens and thus sensing and thinking it differently, both in the process of making and in the audience encounter.

\section{3}

\section{Cinematic Thinking-Feeling}

Cinema shows the world differently through how it sees the world. By seeing the world differently, the viewer then thinks the world differently and is recalibrated to sense it differently. This is a cinematic affect (Deleuze, 2005). In this affective moment of connection, and re-seeing, is an opportunity to make the invisible visible, "the unclear clear, the hidden manifest..." (Vertov \& Michelson, 1984, p. 131) through an aesthetic rupture (Rancière, 2006). This has always been a feature of cinema, however, in the post-analogue context this expands from captured, composed moments in the world to constructed arrays of pixels of any-thing-whatevers.

Filmmakers lean into the artifices of the form which manifest in the miseen-scene (shot composition, production design, colour, performance etc.), and the montage (shot length, order, transition etc.). All of these elements reside in 
the spatio-temporal processes of making, collecting and thinking about the material, which then simmer on the surface of the viewer experience. It is through the potent presence of the maker's hand and voice as they negotiate and lens the world around them, that you sense the moving parts of the whole.

One deep ontological and epistemological motivation for us is the ways in which human being-through-education operates within a wider more-thanhuman ecology - the way in which thinking about the ecology is constrained by the linearity of education systems and attending pedagogies. There's something about how some forms of education that have become seen as the tradition, the norm, the colonial agenda, treat the ecology on account of their attachment to linearity, to progress, and to constant growth trajectories. Linearity is positivistic, evidenced in the tendency of linear thinking to reject the possibility that it's actually not linear at all.

Cinematic pedagogy might have both incremental and subtle, and radical and substantial possibilities for educational and pedagogical thinking. For instance, something new might happen in any one event in any one classroom in any one school and system. And at the same time, something might happen to that whole system as a result of that one event. In doing this work, it is important to recognise first that we are playing with education in both its formal and informal manifestations.

\section{Flying under the Reform Radar}

The value of cinematic thinking when it comes to pedagogy, as we see it, is in a range of ideas about education that don't at first appear to fit within predominant educational traditions - cinematic thinking pushes our pedagogical imaginations into new spaces and configurations. In this sense, we are looking to add to a broad body of 'innovations' that have had arguable impact on educational reform but that nevertheless have an essential role in offering educational communities not just the idea of how to do pedagogy differently, but the idea that it doesn't have to be the way it is.

A challenge in this kind of activity is to generate ideas about pedagogies that have an inbuilt resistance to institutional agendas. In other words, we are hesitant to suggest cinematic thinking as a broad-brush, top-down, orthodox approach for educational reform through which the elements theorised above would appear in some formal and recognisable way in each educational setting. It would make no sense to create a scripted exemplar of visual pedagogy for the future of education. In the history of education reform, great ideas can become tools for maintaining the status quo when recognised and 
assimilated by education systems (see for instance Cuban, 1992).We can see how neat ideas are re-formed and so do very little for educational reform. We see, for example, the failure of innovative learning environments to reform the organisation of the curriculum and the role of the teacher in primary school settings (Deerness et al., 2018).

The grammar of schooling shapes us all. It is quite difficult to escape from the logic, dispositions and customs that result from our own years of immersion in schooling practices. Thus, it takes a major leap-a change in conditions-before we can think differently about schools.

DEERNESS ET AL., 2018, p. 164

In working with visual pedagogy then, we are taking a determinedly under the radar approach, keeping a very safe distance from what we might call the zone of state intervention and the domain of policy. A danger of that deinstitutionalised approach includes a potential failure to challenge existent inequalities and privileges. The criticisms couched in a provocation of preaching to the converted, while predictable, must be heeded. So here we can turn back to Rancière in order to explain the politics of cinematic thinking in pedagogy one possibility through which we understand that it's not the artist's role nor responsibility to teach, in the explicatory sense of the teacher (Guattari, 1995). Cinematic thinking opens up an affective experience of the world when it does not tell us what to think nor how to think - it invites thought and speaks to the possibility of feeling-thinking. In addition, through Rancière we can point to the possibility that addressing issues of structural injustice won't occur through raising new structures, but rather through working without structure. However, this is not a point that we want to enshrine in a text about a cinematic work, it's a point that is invited through the cinematic work itself.

As we finalise this text to accompany the visual material that is Flight, we are locked down, in our homes, because of the powerful invisible force that is the virus CoviD-19. This force is made acutely visible (and audible) by the way it is shaping and changing our different, yet collectively sensed, aesthetic encounters of our new quotidian. Now, our day-to-day encounters with the world are accentuated by the loss of cars on the roads, the sounds of birds in the air, the empty buses relentlessly completing their timetabled journeys, walkers, joggers, and cyclists, renegotiating space, rethinking two metres, a new awareness of our hands and faces, and an absence of jets flying across clear blue skies. 
In this context the work Flight may take on a transitional meaning from art to archaeological artefact. Perhaps now the work is more archive than database.

The ideas that fed the filmmaking practice were steeped in a deep melancholy for a world caught in ecological emergency. The films were attuned to help both the maker and the receiver of the work recalibrate their seeing/ hearing fragments of daily life in the late-modern anew, as an alternate way to sense it and then think about it differently. As makers and thinkers, the same methods present themselves as potentials for coping through this new human emergency. How might we render that which is invisible, in this day-to-day extraordinary shift, visible in meaningful ways, such as we may rethink our affective responses to our new reality?

\section{References}

Camus, A. (1991). The myth of Sisyphus, and other essays (1st Vintage international ed.). New York: Vintage Books.

Cuban, L. (1992). Why some reforms last: The case of the kindergarten. American Journal of Education, $100(2)$, 166-194.

Deerness, S., Gibbons, A., Gilligan, M, Breen, G., Denton, A., \& Heraud, R., (2018). Questions concerning innovative learning environments: Intersections in disciplined resistance. In L. Benade \& M. Jackson (eds.) Transforming education: Design and governance in global contexts (pp. 149-166). Singapore: Springer.

Deleuze, G. (2005). Cinema 2: The time-image (H. Tomlinson \& R. Galeta, Trans.). London: Continuum.

Denton, A. (2018a). Flight.

Denton, A. (2018b). Crude.

Denton, A. (2016a). Cinematic affect in a time of ecological emergency. Monash University, Melbourne, Australia.

Denton, A. (2016b). Affective modes of cinematic inquiry: Oil and subjective distance in Crude (2016) and Flight (2016). PAN: Philosophy Activism Nature (12).

Guattari, F. (1995). Chaosmosis: An Ethico-aesthetic paradigm. Bloomington: Indiana University Press.

Rancière, J. (2006). The politics of aesthetics: The distribution of the sensible. London Continuum.

Rancière, J. (1991). The Ignorant schoolmaster: Five lessons in intellectual emancipation. Stanford, CA. Stanford University Press.

Roder, H., \& Sturm, S. (2018). Flight from flight: Composing a pedagogy of affect. Art, artists and pedagogy: Philosophy and the arts in education.

Vertov, D., \& Michelson, A. (1984). Kino-Eye: The Writings of Dziga Vertov. Berkeley, CA. University of California Press. 